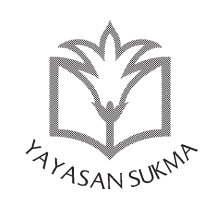

SUKMA: JURNAL PENDIDIKAN

ISSN: 2548-5105 (p), 9590 (e)

Volume 1 Issue 2, Jul-Dec 2017, hlm. 219-248

https://jurnalsukma.org/index.php/sukma/article/view/01201

\title{
BULLYING AT ACEH MODERN ISLAMIC BOARDING SCHOOLS (PESANTRENS) Teachers' Perceptions and Interventions
}

Marthunis; Nailul Authar

Sekolah Sukma Bangsa Pidie, Aceh, Indonesia

email: marthunisbukhori@gmail.com

\section{Abstract}

The study focused on obtaining substantial information of teachers' perceptions and interventions in bullying cases in the environment of modern 'pesantren', Islamic boarding school that facilitates students with formal schooling and dormitory facilities. The study provided an analysis of how teachers at the pesantren conceptually perceive bullying behavior and their concrete actions to prevent the behavior. The study revealed that the pesantren's teachers perceived bullying as dangerous behavior and therefore should be intervened. The study also discovered that the teachers intervened the 
behavior more reactively than proactively. However, their positive perceptions that bullying is detrimental as well as their concrete actions to prevent bullying on their pesantren could not reduce its occurrence significantly. Teasing, mocking or nick-name-calling, for instance, were still found in the researched pesantren. [Tujuan penelitian ini adalah untuk mengetahui persepsi dan intervensi para guru di lingkungan pesantren modern terhadap perundungan. Pesantren terindikasi sebagai tempat yang cukup rentan terjadi perundungan karena interaksi yang terus menerus terjadi antarsiswa, baik di lingkungan sekolah maupun di asrama. Studi ini memberikan analisis bagaimana guru di pesantren secara konseptual memandang perilaku perundungan dan bagaimana tindakan nyata mereka untuk mencegah perilaku tersebut. Penelitian ini juga mencoba mengungkap bagaimana persepsi dan intervensi guru di pesantren terhadap masalah perundungan secara fenomenografi. Penelitian ini menemukan bahwa para guru di pesantren menganggap perundungan sebagai perilaku berbahaya yang perlu ditangani. Para guru di pesantren menggunakan beberapa intervensi dalam bentuk pendekatan reaktif daripada proaktif. Namun, persepsi positif mereka dan tindakan nyata mereka untuk mencegah terjadinya perundungan di dalam lingkungan pesantren tidak dapat mengurangi kemunculannya secara signifikan, terutama mengejek atau menyebut namagelar tertentu sudah cenderung menjadi kebiasaan dan budaya di lingkungan pesantren.]

Keywords: bullying, pesantren, teachers' perceptions, teachers' intervention 


\section{Introduction}

Pesantren is an educational institution for Muslims in Indonesia which usually comprises a pondok (dormitory facility) and a formal schooling (Srimulyani, 2007). "Today, there are generally two kinds of pesantren found almost everywhere in Indonesia, salafi (traditional) and khalafi (modern)" (Raihani, 2001, p. 22). The pesantren salafi (traditional) merely teach the traditional Islamic teachings or kitab kuning (classical Islamic textbook), while pesantren khalafi (modern) adopt formal secular education (Raihani, 2001). In addition, Aceh, as one of the provinces in Indonesia which is regulated by Islamic law, has many Islamic boarding schools which are locally called dayah. Based on the survey of Aceh Islamic Boarding Schools Board for Education and Development (Badan Pembinaan dan Pendidikan Dayah, 2016) in 2014 there were 1.054 pesantren in Aceh (634 traditional and 420 modern).

Moreover, Aceh, with its Islamic principles, tries to uphold Islamic values as the most important aspect in the lives of Acehneses, also in education (Nilan, 2008). Religious values become the most vital educational standard and goal for most parents in Aceh. As a result, they send their children to pesantren to achieve these objectives. The trend of sending children to pesantren started in the last two decades. Before the peace agreement between Indonesia's government and the Free AcehMovement (Gerakan Aceh Merdeka, GAM) in 2005, most traditional Muslim communities sent their children to pesantren salafi to avoid the conflict, since the institutions are respected by both GAM and the Indonesian National Army (Tentara Negara Indonesia, TNI) (Vignato, 2012). Recently, parents from moderate Muslim families send their children to pesantren khalafi in order to protect them from the negative influence of the westernized cultures and values and to internalize strong Islamic values (Nilan, 2008).

The form of modern pesantren was initially pioneered by pesantren Gontor in 1926 (a pesantren in Ponorogo, East Java), and now it is becoming one of the most favorite types of educa- 
tional institutions in Indonesia, including Aceh. The integration between religious instructions and secular studies, the implementation of 24 hour supervision, and the emphasis on using Arabic and English as the languages of instruction makes these kinds of institutions preferable to most parents (Pohl 2006; Hady, 2012). The authors will limit the research object of this study to the modern pesantren.

Respecting others and not harming anybody physically, mentally and socially is one of the objectives in Islamic teaching within the pesantren setting. Those religious instructions are strongly present in the modern pesantren atmosphere. However, there are still behavioral problems among santri (the student), including bullying.

Santri (the students) in the modern pesantren spend 24 hours in their campus, where continuous interaction takes place. They share most of their time in the classrooms, dormitory, bedrooms, mosque, canteen, or bathrooms. Consequently, the intense interaction leads to the higher possibility of bullying to occur (Pfeiffer \& Pinquart, 2014). In terms of preventing bullying, modern pesantren is therefore demanded to have more responsibility to address bullying issues. Accordingly, teachers of a pesantren have a vital part in recognizing, perceiving, and preventing such behaviors. Expressing empathy and perceiving the seriousness of bullying situations are among the steps before implementing the intervention, since "teachers' perceptions of the situation affect their abilities or willingness to intervene" (Beebout-Bladholm, 2010, p. 9). Similarly, in another study, Dake, Price, and Telljohann (2003, p. 177) also commented that "teachers' perceptions of bullying may influence when and how willing they are to intervene."

Besides perceptions, the issue of intervention against bullying is also important to be elaborated in this study. Crothers (2008, p. 132) remarked that "intervention is critically important in preventing and reducing children's behavior problems," including bullying, since it can be influential toward students' 
academic achievement, social and their emotional well-being. Consequently, the study of teachers' perceptions and interventions employed against bullying at the modern pesantren in Aceh is urgently needed to be conducted as Pfeiffer and Pinquart (2014, p. 581-582) proposed that "studies of bullying in boarding schools are important, because students meet the same peers as well as the same bullies at school and in their residential setting."

\section{Review of Related Literatures}

\section{How Teachers Perceive Bullying Behavior}

Bullying is becoming a nightmare and one of the major behavior problems within school environment around the globe (Aluede, Adeleke, Omoike, \& Afen-Akpaida, 2008). “In Canada, 15 percent reported bullying others more than twice a term while 9 percent of children reported bullying others on a weekly basis" (Charach, Pepler, \& Ziegler, 1995, as cited in Craig, Henderson, \& Murphy, 2000, p. 6). In the United States, there are about 70 percent of all students affected by bullying (Kennedy, Russom, \& Kevorkian, 2012). Therefore, teachers as the main figure in the educational processes in schools' setting are expected to be the ones who are able to cope with bullying problem. Teachers have a vital role to reduce the issue within schools' environment. As Rabah and Vlaardingerbroekt (2005) verified in their study that teachers have a significant part in overcoming the problematic issue of bullying behavior.

Many teachers do not perceive bullying problem as a serious issue. However, their seriousness in perceiving and dealing with this issue influence their willingness for prevention and intervention (Dake et al. 2003; Beebout-Bladholm, 2010). Pepler, Craig, Ziegler, and Charach (1994, as cited in Craig et al. 2000) reported that teachers actually tend to intervene bullying. However, the teachers' interventions against bullying behavior only had been reported by 35 percent of students. Likewise, Olweus (1984) in a questionnaire study found that about 40 percent of elementary 
students and 60 percent of junior high students reported that teachers' attempt to intervene bullying only once in a while or almost never (Craig et al. 2000). In addition, the study conducted by Unnever and Cornell (2003) showed that most of junior high students perceived that their teachers rarely try to intervene bullying (Kennedy et al. 2012).

Similarly, Batsche (in Bear, Minke, \& Thomas, 1997, p. 176) reported that "the response of school personnel to bullying is, at best, disappointing, and results of research conducted at different times and in different countries provide a similar picture." In a research investigated by Stephenson and Smith (1989) was found that about $25 \%$ of teachers thought that ignoring bullying was a good idea, because the occurrences of the problem were often in the form of verbal assault, withdrawal or isolation; thus, they probably perceive that these behaviors were not considered as serious issues. Boulton and Underwood (1992) also found that the frequency of bullying intervention reported by teachers was more than the frequency reported by students. Consequently, the bullied students perceived that the teachers did not concern of their problems and even considered them as being unable to protect students from the aggressive behaviors (Batsche in Bear et al., 1997).

Essentially, if a teacher perceives bullying problem as a dangerous behavior which can bring long-term effect, she might do something to assist a child whenever she reports for having been bullied by others. Otherwise, if a teacher expresses little sympathy for the victim, she/he might do less to help a child who reports of being bullied by his/her friends (Boulton, 1997). Misinterpreting other's behavior as bullying is also a problem to perceive bullying inaccurately (Boulton, 1997; Hazler et al., 2001). Thus, in order to perceive bullying correctly, teachers must be able to identify bullying in all of its forms.

Additionally, teachers' abilities to identify bullying behaviors accurately and decide appropriate ways to interfere bullies and victims are often mystified by different definitions to assess 
bullying within the literature (Hazler et al., 2001). Monks and Smith (2006) also explained that usually the school staffs who define bullying behavior differently are not only teachers but also other school personnels. Moreover, Marshall et al. (2009) discussed a study conducted by Hazler et al. (2001) which they found that even teachers and school counselors have different ability to distinguish bullying behavior from other forms of children play and violence. A similar model was also described by Tepetas, Akgun and Altun (2010, as cited in Goryl et al., 2013, p.33) who found the preschool of Turkish teachers that they could not identify well bullying behavior and only define it as physical attack or defiance behavior, and they did not consider psychological or verbal types of bullying.

Considering the different perceptions to see and distinguish between the acts of bullying and other types of youthful play, many teachers will probably respond mistakenly toward bullying report. This dilemma will lead to the students' reluctance to report that they are being bullied. Oliver and Candappa (2007) criticized that students feel hesitant to report bullying because of inappropriate responses obtained from their teachers. In a research conducted by Boulton and Underwood (1992), "a survey of 296 pupils aged between eight and eleven years from three middle schools, they found that only a third of respondents reported that teachers almost always try to stop bullying in school" (Oliver \& Candappa, 2007, p. 72.). Thus, the fact that many teachers perceive or define bullying differently could probably be one of the factors why most of teachers may do less or intervene inaccurately toward bullying problems.

\section{Bullying and interventions}

As previously discussed, many teachers do not involve efficiently in intervening bullying due to the difference perceptions of bullying definition. Based on a study by Clarke and Kiselica (1997), they showed that teachers do not respond appropriately to many bullying reports within school areas. Their 
study portrayed that about 33.6\% students in England answered 'sometimes' or 'almost never' toward the frequency of teachers' intervention on bullying behavior (Bauman \& Hurley, 2005). Additionally, in a study conducted by Bauman and Hurley (2005) they discovered that the majority of teachers (88\%) perceived themselves to intervene well the bullying episode in school, while only $20 \%$ of students believed that teachers have a sufficient supervision toward bullying behavior. These findings reveal that the willingness of teachers in preventing and intervening bullying within school environment is lower than just perceiving them as the phenomena that are in need of proper attention.

Mann, Kristjansson, Sigfusdottir, and Smith (2015) proposed that the efforts to intervene bullying can be the ones focused on empowering individuals, educational institution, or other external aspects such as society or family. Bullying on the individual-focused intervention is seen as relying on salience of the personal effect or outcome. A practical step of individual-focused intervention is through identifying properly a susceptible child or student involved in bullying and help him/her with effective counseling processes. In an educational institution-focused intervention, bullying is a school product (e.g. school culture or school climate). In this type of intervention, school personnel and administrator try to concentrate on creating school's climate as the safest place against the bullying behavior. Moreover, in society or family-focused intervention, bullying is believed as the result of family and community interaction. This sort of intervention focuses on encouraging of how family and community members synergize to develop a social support network by having good communication each other to prevent children in a particular family of community to do bullying (Mann et al., 2015).

$\mathrm{KiVa}$ is another bullying intervention program which has been tested and developed in Finland. Salmivalli et al. (2010, as cited in Williford, 2012) described that KiVa program perceives bullying as a group process in which the bully acts assertively for obtaining higher peer-group status and the behavior is repeatedly supported by the ignorance of bystanders. Additionally, 
the program is designed to reinforce students' involvement to prevent bullying among their peers and also to defend victims from the bullies. Basically, the KiVa program emphasizes the enhancing of bystanders' abilities to support victimized friends. A recent study by Jeffrey (2004) reported that peers present in $85 \%$ of bullying cases, but they intervened in only $10 \%$ cases. To reinforce bystander's reaction is another crucial issue to prevent bullying problem (Padget \& Notar, 2013). Implementing KiVa program by reinforcing peer involvement in bullying episode to act as defender bystander is significantly important to reduce bullying within school environment, because the study by Williford et al. (2012) affirmed that the implementation of the program was able to downgrade the problem effectively.

The final model of bullying intervention discussed in this chapter is the whole school approach model. The program is known as Olweus Bullying Prevention Program (Cecil \& MolnarMain, 2014). Ecologically, the whole-school approach considers all levels of the environment in the context of the relationship to school. It offers the prevention and intervention approaches with a variability of level of school ecology. At the school context, all school personnel and students are trained equally to obtain the substantial information regarding bullying behavior and the strategy to respond it. School policy is also needed to address appropriate intervention. At the classroom level, teachers must be able to hold a weekly classroom meetings and instructional curricula regarding the issue. Students must be trained well toward bullying situation by using pro-social behaviors (Olweus, 1993; Smith, Schneider et al., 2004, as cited in Losey, 2009).

\section{Research Methodology}

As a qualitative research, this study used participant observation and in-depth interview to explore teachers' perceptions and their interventions toward bullying issue at the modern pesantren in Aceh. Participant observation was conducted by both observing and participating in daily and regular activities 
which were relevant to the purpose of this study. Doing informal conversation and interaction with members of the study were also conducted to gain meaningful information. The in-depth interviews were voluntary and anonymous. The participants were also free to decline any questions they did not wish to answer.

Among the five cities in Aceh, that is Banda Aceh, Sabang, Lhokseumawe, Langsa and Subulussalam, the statistics in 2014 showed that Lhokseumawe and Banda Aceh have the highest numbers of the modern pesantren (37 and 26) with the highest number of santri (students studying in the pesantren) as well (5.894 and 4.190) (Statistics of Aceh Province, 2016). Therefore, the researchers selected one modern pesantren of each municipality to be studied.

The two selected modern pesantren were chosen as each has its own unique characteristics. The modern pesantren in Banda Aceh had a thousand students coming from the entire Aceh province with different family background, local languages, and cultures. The second pesantren was located in Lhokseumawe, a city where regional conflict between the Free Aceh Movement (Gerakan Aceh Merdeka, GAM) and The Indonesian National Armed Forces (Tentara Nasional Indonesia, TNI) had taken places. Most of the students were coming from the former GAM combatants' family. The students' experiences of being exposed to conflict in the past were assumed to be more potentially triggering bullying.

Ten teachers of the selected pesantren from both regions were asked to voluntarily participate in the study. All of the interviewees were the teachers working at the dormitories. They were chosen because their main responsibilities were supervising students' interaction and preventing harmful behaviors from occurring among their students, including bullying.

In addition, in order to triangulate and confirm the data from interviewed teachers, the researchers also interviewed some students in each pesantren (three students from the pesantren in Lhokseumawe and four students from the pesantren in Banda 
Aceh). Those students were selected based on the criterion that the students had to be the victims of bullying.

The in-depth interviews were recorded, transcribed, categorized and analyzed using the interpretative phenomenological and phenomenographical analysis. In doing the analysis, the researchers concentrated on the collective experience of the participants. Particularly, the transcribed interviews were deliberated as a unified dataset, and the individual participant's answers were not the concentration within this present study. The variation of the ideas that phenomenography searched for was discovered within the range of experiences and understanding of the whole sample group-as a group's participants-not in the range of experiences of each individual in the sample.

\section{Teachers' Perceptions of Bullying Behavior}

After transcribing and coding the interviews data, the researchers constructed four categories of description based on teacher participants' utterances concerning their perceptions of bullying behavior. These four categories were taken from four different perceptions of the bullying problem: bullying is related to teasing, mocking or name calling; bullying is related to the physical attack of seniors to juniors; bullying is related to threatening; and bullying is caused by school culture.

\section{Category 1: Bullying Related to Teasing, Mocking or Name Calling}

Teacher participants in this study perceived bullying behavior as closely related to teasing, mocking or name calling. Because phenomenography concerns on people experience to understand the phenomenon in the world around them, it is important to notice that in Category 1 the participants referred bullying behavior to the teasing, mocking or name calling phenomenon within pesantren environment. This category had two subcategories: (1) positive - teasing, mocking or name calling can lead to build positive engagement with peers and (2) negative - 
teasing, mocking or name calling to humiliate others or bring to another harmful behavior such as fighting.

Teasing, mocking or name calling is perceived as positive as "a habit and part of tradition within pesantren environment" (IMU05-school culture-LC) and ... "being teased or called by nasty name (laqab) is considered familiar in pesantren atmosphere" (IDU02-school culture-LC)

Based on the informants' answer regarding the Category 1, it can be seen that the idea expressed in the Category 1 (bullying was related to teasing, mocking or name calling) was closely linked to Category 4 (bullying was caused by school culture). The connection can be seen from the answer of the participants that teasing, mocking or name calling had been already a habit and a tradition in the pesantren environments. In other words, teasing, mocking or name calling were seen as acceptable and rooted in students' interaction in the pesantren.

As a comparison, the study of bullying perception has been examined in many studies (such as Boulton, 1997; Hazler et al. 2001; Dake et al. 2003; Beebout-Bladholm, 2010). Those studies described that many teachers have different views in perceiving bullying. Most of them, however, tend to emphasize the physical forms of bullying and ignore verbal and social forms of bullying. In the writers' study, the teachers at the pesantren noticed that the occurrences of bullying are more in the form of verbal bullying (e.g. teasing, mocking or name calling).

As previously explained, Category 1 (bullying is related to teasing, mocking or name calling) was the most common type of bullying which appeared during the interviews. The teacher participants described that teasing, mocking or name calling is the most frequent form of bullying occurring among students' interactions in pesantren.

Additionally, the teachers in the pesantren sometimes faced difficulties in judging the teasing behavior, whether they were actually just humorous acts or conversely as humiliating conducts. It was as humor was considered as prosocial behavior, 
while humiliating was regarded as bullying. That was why the teachers at the two pesantren experienced difficulties in intervening teasing behavior, especially as the perpetrator considered it a humorous act, while the victim perceived it as a humiliating conduct.

\section{Category 2: Bullying Related to the Physical Attack}

The perceptions that bullying is related more to physical attack from the seniors over their juniors were revealed several times during the interviews. The informants explained that in many occasions such physical attack was preceded by unacceptable teasing, mocking or name calling acts. One of the stories is as follow which had happened a week before the interview.

There was a student in grade 8 hit his junior in grade 7 because he could not accept of being mocked by his junior (IMU03-seniors bully juniors-BP). Another student of grade 11 who took two pieces of chicken at the pesantren cafeteria when dinner time was teased by his junior of grade 10 by calling him greedy since a student could only take a piece of chicken. Because he felt humiliated, he punched his junior in front of many other students (IDUS01-seniors bully juniorsBP).

The phenomenon of seniors physically attacking their juniors took place frequently in the pesantren. Beside the unacceptable teasing, mocking or name calling acts, it was also caused by the pesantren's policy handing the senior students of grade 11 and 12 the authority to discipline their juniors. Assuming their having power and authority to manage their juniors, it often makes them uncontrollably attack their juniors physically. Therefore, Category 2 (bullying is related to the physical attack of seniors on juniors) can be linked to Category 4 (bullying is caused by school culture).

From the interviews, the teachers described that physical attacks of seniors over their juniors frequently happened. They explained that it was more because the pesantren management 
and policy authorizing senior students (grade 10 to 12) to discipline their juniors. The 'abuse of power' was also revealed taking place because the seniors wanted to prove their existence.

Theoretically, the phenomenon of seniors physically attacking or bullying their juniors can be described using the theory of social identity (Tajfel \& Turner, 1979). The theory offers that an individual's belief and perception toward in-group and outgroup elements originate from a desire to recognize that his/her group is better or superior compared to other groups. The result of this process will direct a particular person to show his/her favoritism to in-group members. On the other hand, the person will discriminate against out-group members since he/she perceives out-group members as being different from his/her own group. Therefore, most of the senior students at the pesantren keep bullying their juniors in order to prove their existence and to show the superiority of their group compared to other groups.

\section{Category 3: Bullying Related to Threatening}

Threatening is one of bullying forms, and it also occurred in the studied pesantren. The interviewed teachers and students perceived bullying as also in forms of threatening which took place in the students' interaction. Psychologically, threatening is considered detrimental as it causes victim's mental distress. A teacher explained:

Sometimes I found students who are hesitant to report of being bullied by peers because the perpetrator threatened the victim that the victimization would be worse if he reported to teachers regarding bullying occurrence (IDUS01-threateningBA).

The teacher also described that "... there was a victim who felt doubtful to report bullying because he was afraid that most of the perpetrators would get mad at him" (IMU02-threateningBA).

Based on the description of Category 3 (bullying is related 
to threatening), it can be noticed that it has a close correlation with Category 4 (bullying is caused by school culture). The pesantren culture has the slogan ukhwah islamiyah which means Islamic solidarity. Essentially, the value of Islamic solidarity is positive because it obligates every Muslim to be kind and helpful for others in every occasion. But, some students in the pesantren understood the value of solidarity mistakenly. They assumed that teasing, name calling, mocking or physical abuse was conducted as a medium to build and maintain solidarity and in turn it becomes a culture and tradition in pesantren. So, consequently, bullied students felt hesitant to report bullying to their teachers, not only because the victims were afraid of the perpetrators but also because the perpetrators' friends were also participating in threating them. It then made the victims felt stressful.

The findings also revealed that teachers perceived threatening as a part of bullying behavior. The teachers explained that some students felt worried and hesitant to report being bullied to teachers because they were threatened by the perpetrators. If they had been reported, things would be worse.

Bullying in the form of threatening and its relationship with what was called 'the pesantren culture' can be explained by using the socio-cultural theory as developed by Hancourt et al. (2014). The theory explains that bullying as a complex social phenomena is affected by many social variables surrounding a child such as school, home, peer, and community environments. Even a very young child is profoundly surrounded by a complex social environment with a continuous interaction and communication of the actor and the environment. In this theory, bullying needs to be perceived in the cultural context of the organization where it originates. This theory also offers to see bullying as a behavior connected to the community. Therefore, the continuous interaction among students within the pesantren community with the permissiveness against bullying behavior (e.g. teasing, mocking, name-calling or even threatening) makes the issue to stay longer and transform the culture and tradition within the pesantren environment. 


\section{Category 4: Bullying Caused by School Culture}

Bullying was perceived closely related to school culture. As previously mentioned, Category 1 (bullying is related to teasing, mocking or name calling) and Category 3 (bullying is related to threatening) have a strong correlation to Category 4 (bullying is caused by school culture). Bullying frequently occurred in pesantren environment, especially in forms of teasing, mocking or name calling. Teachers in the pesantren also faced difficulties in identifying this type of bullying as whether they were intended as humors or humiliations, especially as they have become a habit or and tradition within pesantren community. Another issue was that most of the victims were hesitant to report if they were bullied by their peers, mainly because the perpetrators threatened them that their acts could be worse. The phenomenon was described as follows.

Whenever a student tried to report of being teased or mocked by his friends, the frequency of teasing would be worse. Even the bullied student would be labelled as coward by his peers if he told the teachers that he had being bullied (IMU05-school culture-LC).

As a consequence, the victims started defending themselves from being teased or mocked by teasing or mocking others as well. It then created an endless circle of bullying within the pesantren and gradually became a culture.

Theoretically, the occurrence of bullying was not in isolation, but it was a result of the complex relationship among many integrated systems such as individual, peer group, family, school, community, and culture. It confirms the phenomena within the pesantren environment. The suspected bully was a student who belonged to a group of bullies (microsystem). Two social settings in the pesantren, school and dormitory, made the occurrence of bullying more vulnerable (mesosystem). As discussed by Pfeiffer and Pinquart (2014), bullying at boarding school is likely to befall more often because students meet the same bullies at school and their dormitory. The more the contact among the students, the 
higher the possibility of bullying to occur (Pfeiffer \& Pinquart, 2014).

In addition, bullying behavior (e.g. teasing, mocking, or name calling) essentially was stated in the handbook of student discipline guidance (GDS) as a form of violation on the pesantren rules. Yet, it was not understood well by all of the pesantren's elements. That was why bullying was still vulnerable to happen at the institution (exosystem). Finally, the pesantren culture and tradition in forms of teasing, mocking, or name calling made bullying subsisted within the environment (macrosystem).

\section{Teachers' Intervention to Prevent Bullying}

There were five categories in relation to teachers' interventions in preventing bullying behavior in the pesantren: intervening by pesantren policy, intervening by advising, intervening by mediation, intervening by parents' meeting, intervention by physical sanction.

\section{Category 5: Intervening by Pesantren Policy}

One of the interventions to prevent bullying was through issuing pesantren policy. Both pesantren had similar regulations regarding the issues of bullying. There was a handbook called Gerakan Disiplin Santri, a guide for student's discipline. It discussed the pesantren's regulations in details and the punishment for every violation, including bullying. One pesantren divided the level of violation into three levels: diminutive breach of conduct, average breach of conduct, and severe breach of conduct. A teacher explained it as follow.

Bullying in the form of teasing, mocking or name calling was considered at the level of diminutive breach of conduct. The punishment given by teachers for this type of violation was usually an advice to stop doing it again. But, if the occurrence of teasing, mocking or name calling lead to physical abuses or even fighting, because the teased student resisted of 
being teased, the violation was regarded as severe breach of conduct. The physical sanction for this breach was to have the hair cut completely off (IMU01-school policy-LP).

Basically, teachers' intervention is related to how teachers perceive bullying behavior. Many studies discussed that most of teachers do not perceive bullying correctly or appropriately, thus, their responses and interventions are also not effective. This study found that all interviewed teachers perceived bullying as a serious problem to cope with. Beside physical and social bullying, they agreed that the occurrence of verbal bullying in the form of teasing, mocking or name calling should be reduced, since those behaviors led to other negative forms of aggression such as fighting. Therefore, they expressed several types of interventions to prevent bullying.

The pesantren's policy actually included teasing, mocking, or name calling as a form of acts that violate pesantrens rules. It was categorized as the medium level of rule's violation. The punishment for this type of violation was usually in form of social works such as cleaning bathroom and dormitory's porch, and the punishment could be worse if the students breached it repeatedly. Our observation also discovered that although bullying is considered as form of policy's violation, bullying still frequently happened in the pesantren. Most possibly it was as the detrimental effects of bullying behavior was only realized well by some teachers. The teachers who were not in charge at the dormitory, for instance, tended to ignore it, since they assumes that it was not their responsibilities.

Therefore, it could be seen that not all teachers in pesantren commited to prevent bullying and obviously there were no systemic cooperation among teachers to cope with the issue. Such situation made bullying potentially grew rapidly and lasted longer. The circumstance also reflected the ineffectiveness of pesantren's policy as there was no whole school approach model as the Olweus Bullying Intervention Program suggested. 


\section{Category 6: Intervening by Advising}

Most interviewed teachers expressed that the initial step to prevent bullying was by advising students to not doing such behavior. The frequency of giving advice related to the danger of bullying was quite frequent, since most of them gathered with students at least once a week.

The strategies that I usually use to deliver the advice for students regarding bullying are in two ways; gathering all dormitory students or one to one advice (IMU01-intervening by advising-IN).

The teachers described that the intention of gathering all dormitory students was to advise them in order to build an equal comprehension and awareness that bullying must be avoided. Individual discussion was usually used to facilitate the suspected bully. It was aimed to gather information of why the bully bullied others, and this strategy was also used to build positive communication with the bully to prevent him from doing such behavior.

The category was closely related to Category 5 (intervening by using pesantren policy). Delivering advice as part of intervention to prevent bullying has been stated in the handbook of students discipline guidance (GDS). It was also in line with what the interviewed teachers revealed that delivering advice to prevent bullying was applied as an initial procedure. Even delivering advice was one of the most common strategies deployed by the teachers in pesantren to intervene bullying behavior.

The teachers usually delivered their advices using two ways: telling the students in a gathering at once or one to one or individual advice. In a gathering, the students were advised about the detrimental effects of bullying as well as to build sufficient understanding and awareness on bullying and that it should be avoided. On the other hand, one to one advice was used to advise the suspected bully in order to understand why he bullied others and to build positive communication with him that he would not conduct it again. 
Basically, this strategy is quite similar to the method of shared concern. It is a non-punitive intervention to interfere student that is identified as bully. The one-to-one interview is employed in the method. The aim of the method is to gain the acknowledgement from the suspected bully that there is a child who is having a hard time and feel stressful because of bullying. In this method, the interaction can be more intimate, and the teacher is also able to advise the bully more deeply with the main aim is to disengage him from the destructive behavior.

\section{Category 7: Intervening by Mediation}

Mediation is another type of intervention utilized in pesantren to prevent bullying. Some of the interviewed teachers described that they used mediation to intervene bullying issue:

I usually mediated students involved in bullying. I invited both bully and the victim to come to my office and asked them one by one about the chronology of the incident without interrupting. After getting the comprehensive information regarding incidents, I asked the bully to think of the solution in order to recover the situation. In the end, I required them to handshake as the symbol that the problem is solved (IMU04intervening by mediation-IM).

This form of intervention was also similar to the mediation approach studied earlier. The steps applied were also alike. In this approach, the students were engaged in the process of finding a mutually acceptable solution. The strategy also produced a high level of creative engagement to find an agreed solution on their problems.

This type of intervention is a part of individual-focused intervention. It is mainly aimed at identifying vulnerable students involved in bullying and mediate them to cope with the problem. In the individual-focused intervention perspective, bullying is seen as a personal effect or outcome. The concrete step of the individual-focused intervention is to identify properly a susceptible child or student involved in bullying and facilitate him to 
Bullying at Aceh Modern Islamic Boarding Schools (Pesantrens)

find an effective counseling process to get out of the problem.

\section{Category 8: Intervening by Parents' Meeting}

Another type of intervention which was commonly deployed in pesantren was parents' meeting. What we mean by parents' meeting in this study was to invite parents' of the bully and victim to attend the meeting in order to moderate and overcome the problem. But, inviting parents to attend the meeting due to behavior problem was often understood as the sign of severe breach of the conduct according to the pesantren policy. When the breach was repeated, it even might end with suspension or expulsion from the pesantren.

Whenever a particular student involved in bullying for several times, his parents would be invited to attend a meeting in the pesantren. In the meeting, his parents would be told of the violation that had been done by their children. The bully would also be warned for the possibility of being expelled from the pesantren if he repeated the bullying behavior (IMU03-intervening by parents' meeting-IO).

An interviewed teacher also expressed that,

Not all parents who were invited to the meeting were cooperative with the pesantren staff, because some of them tried to blame the regulation and teachers' supervision regarding the bullying which was conducted by their sons (IDU03-intervening by parents' meeting-IO).

Based on the information from the participants, we also found that to deal with parents concerning bullying problem is a challenge. Some parents are cooperative and try to help the teachers in advising their son for not bullying his peer. Otherwise, some other parents attempt to blame the teachers and complain about the rules or policy of the pesantren. Therefore, the intervention through parents' meeting in order to prevent bullying tend to be successful if the children involved in the bullying belong to the cooperative parents. But, if the parents are not supportive, 
the treatment is not effective.

Parents' meeting was basically intended as a medium to inform the bully's parents concerning the negative behavior of their son in his interaction with his friends. It was essentially expected that parents could effectively advise their children to get rid of such negative behavior. The assistance from parents in advising their children was also aimed to raise the bully's awareness of the detrimental effects of bullying, that the bully could decide to stop doing it. This intervention is a part of family-focused intervention since bullying was also believed as the result of family or community interaction. The intervention was intended to encourage family, especially parents, synergize to develop a social support network by having good communication one another to prevent their children from bullying.

\section{Category 9: Intervening by Physical Sanction}

What was meant by physical sanction in this research was not physical violence or abuses such as slapping, hitting, kicking or punching. Those forms of punishment were applied a few years ago. Physical sanctions here could be like asking the punished students to stand under the sun for a few hours or completely cut the students' hair off.

For the students who bullied his peers repeatedly and his conducts triggered more harmful behavior such as fighting, the punishment could be completely cutting their hair off or be humiliated to stand under the sun for some hours in front of the other students (IMU01-intervening by physical sanction-IF).

If a bully student had been reminded several times for not bullying others, but he still did so, I will call him to my office, and the sanction for him will be cutting his hair completely off (IDU01-intervening by physical sanction-IF).

As a form of physical sanction, cutting students' hair off was one of the most popular sanctions in pesantren for severe 
Bullying at Aceh Modern Islamic Boarding Schools (Pesantrens)

breach of conduct, including bullying. Having one's hair cut off was culturally the symbol of disgrace and disobedient. Whenever a student was punished by cutting his hair completely off, he would be labelled as a disobedient student within the pesantren community. Having this label, the student would be shy, and the label was expected to provide a deterrent effect for the student in order to stop conducting bad behaviors.

These interventions have the similarity with one of the reactive approaches proposed by earlier research called direct sanction. The intervention like cutting one's hair completely off and standing under the sun are types of reactive punishment rather than proactive. The consequence of those punishments could not be positive, since it might just humiliates the bully for temporarily and the bully are not engaged in constructing positive values in the intervention. If the bully stops bullying others after getting the sanction, it cannot be seen as resulting from his understanding or awareness of the destructiveness of bullying, but it is more because of he is being afraid of the sanction. The intervention does not encourage any critical and creative engagement of the bullies to disengage from bullying. Therefore, it is possible in the future that he will bully again whenever he assumes that he can avoid punishment.

\section{Concluding Remarks}

There are several implications that can be drawn from the study. First of all, we can see that bullying behavior in the form of teasing, mocking or name calling (Category 1) lasts longer in pesantren environment. It is because the habit and tradition to call others by improper names is considered acceptable by most students at the pesantren. This acceptability makes the behavior evolve as a pesantren's culture (Category 4). This circumstance implicates the difficulties of the teachers to identify whether the behavior is a form of humor or a humiliation, and it leads to the complicatedness of how to cope with the problem. Even though the pesantren's policy restricts teasing, the policy is not 
effective enough to reduce the problem. The ineffectiveness of the pesantren policy's implementation implies two issues. First, majority of students lack understanding of the detrimental effects of bullying behaviors; second, the prevention of bullying is not applied by using the whole school approach, and, therefore, the seriousness of bullying intervention and prevention is only understood by several teachers who are in charge as dormitory teachers (Category 5).

Moreover, the types of intervention deployed by the teachers in pesantren are merely based on reactive approaches. The intervention using school policy, the interventions by advising (Category 6), mediation (Category 7), parents' meeting (Category 8), and physical sanction (Category 9) belong to the reactive approaches, which tend to only solve the problem in a short-term. As suggested by earlier research, using proactive or preventive strategies by manipulating or controlling the situation are proven functional. KiVa model which was developed by Salmivalli, for instance, a Finnish professor in psychology, is worth trying. The model suggests that bullying occurs frequently within a school community because of the ignorance of bystanders or onlookers. The bystander usually tries to pretend to be unaware of bullying behavior.

Thus, by building an awareness for every student to be a defender-bystander who wishes to help the victim in every bullying will effectively downgrade the problem. Consequently, a very clear practical implication of the research findings is that teachers and students must equally be trained in order to have the same perception that bullying is dangerous for the victim socially, mentally or even physically. The pesantren's policy (Category 5) in terms of bullying, not only in the form of teasing, mocking or name calling but also in any other types, must be understood well by all elements in pesantren's community.

The study revealed that the teachers in the pesantren perceive bullying as dangerous behavior that should be intervened. The study also discovered that the teachers in the 
Bullying at Aceh Modern Islamic Boarding Schools (Pesantrens)

pesantren deployed several interventions in forms of reactive approach rather than proactive. However, it was found that the teachers' positive perception (bullying is harmful) and their concrete action to prevent bullying in their pesantren could not reduce its occurrence significantly. What happened was that bullying conducts such as teasing, mocking or name-calling became habit, tradition, or culture in the pesantren environment.

The findings regarding teachers' perceptions and their interventions of bullying behavior in the research certainly require further research. For example, it would useful to conduct similar research at a non-pesantren school. While interventions in the two researched pesantren tend to be reactive, it is also useful to conduct an action research in which proactive approaches are simulated and can be practiced.

Another interesting and important form of research can be conducted at a school with a strong no-bullying culture. Not only it will map out how the culture is and has been constructed, a comparison with other school cultures will enrich the map. 


\section{BIBLIOGRAPHY}

Aluede, O., Adeleke, F., Omoike, D., \& Afen-Akpaida, J. (2008). A review of the extent, nature, characteristics and effects of bullying behaviour in schools. Journal of Instructional Psychology, 35(2), 151-159.

Ashiabi, G. S., \& O'Neal, K. K. (2015). Child Social Development in Context. SAGE Open, 5(2), 2158244015590840.

Bandura, A. (2001). Social cognitive theory: An agentic perspective. Annual review of psychology, 52(1), 1-26.

Basyiruddin, F. (2012). Hubungan antara penalaran moral dengan perilaku bullying para santri Madrasah Aliyah Pondok Pesantern Assa'adad Serang Banten.

Bauman, S., \& Del Rio, A. (2005). Knowledge and beliefs about bullying in schools comparing preservice teachers in the United States and the United Kingdom. School Psychology International, 26(4), 428-442.

Bauman, S., \& Del Rio, A. (2006). Preservice teachers' responses to bullying scenarios: Comparing physical, verbal, and relational bullying. Journal of Educational Psychology, 98(1), 219.

Bauman, S., \& Hurley, C. (2005). Teachers' attitudes and beliefs about bullying: Two exploratory studies. Journal of School Violence, 4(3), 49-61.

Bear, G. G., Minke, K. M., \& Thomas, A. (1997). Children's Needs II: Development, Problems and Alternatives. National Association of School Psychologists, 4340 East West Highway, Suite 401, Bethesda, MD 20814-9457.

Beebout-Bladholm, T. M. (2010). Teachers' Responses to Bullying Situations: The Elements that Influence Intervention. ProQuest LLC. 789 East Eisenhower Parkway, PO Box 1346, Ann Arbor, MI 48106.

Boulton, M. J. (1997). Teachers' views on bullying: Definitions, attitudes and ability to cope. British Journal of Educational Psychology, 67(2), 223-233.

Cecen-Celik, H., \& Keith, S. (2016). Analyzing Predictors of 
Bullying at Aceh Modern Islamic Boarding Schools (Pesantrens)

Bullying Victimization with Routine Activity and Social Bond Perspectives. Journal of Interpersonal Violence, 0886260516672941.

Cecil, H., \& Molnar-Main, S. (2015). Olweus Bullying Prevention Program: Components Implemented by Elementary Classroom and Specialist Teachers. Journal of School Violence, 14(4), 335362.

Coffee, A. W. (2004). The influence of personal and environmental factors on teacher preference for intervention in student altercations (Doctoral dissertation).

Craig, W. M., Henderson, K., \& Murphy, J. G. (2000). Prospective teachers' attitudes toward bullying and victimization. School Psychology International, 21(1), 5-21.

Dake, J. A., Price, J. H., \& Telljohann, S. K. (2003). The nature and extent of bullying at school. Journal of school health, 73(5), 173-180.

Espelage, D. L. (2014). Ecological theory: Preventing youth bullying, aggression, and victimization. Theory into Practice, 53(4), 257-264.

Espelage, D. L., Gutgsell, E. W., \& Swearer, S. M. (Eds.). (2004). Bullying in American schools: A social-ecological perspective on prevention and intervention. routledge.

Espelage, D. L., Polanin, J. R., \& Low, S. K. (2014). Teacher and staff perceptions of school environment as predictors of student aggression, victimization, and willingness to intervene in bullying situations. School psychology quarterly, 29(3), 287.

Fontes, N. V. (2014). Voices from the Warfront on the Battle against Bullying: Teachers' Perceptions of Bullying among Male and Female Students within Their School (Doctoral dissertation, California State University, Sacramento).

Fox, C. L., \& Boulton, M. J. (2005). The social skills problems of victims of bullying: Self, peer and teacher perceptions. British Journal of Educational Psychology, 75(2), 313-328.

Gini, G. (2006). Bullying as a social process: The role of group 
membership in students' perception of inter-group aggression at school. Journal of School Psychology, 44(1), 51-65.

Goryl, O., Neilsen-Hewett, C., \& Sweller, N. (2013). Teacher education, teaching experience and bullying policies: Links with early childhood teachers' perceptions and attitudes to bullying. Australasian Journal of Early Childhood, 38(2), 32.

Hady, A. (2012). Pesantren Gontor: its educational reform and contribution to the creation of a prominent santri network. (Doctoral dissertation, The University of New South Wales)

Hazler, R. J., Miller, D. L., Carney, J. V., \& Green, S. (2001). Adult recognition of school bullying situations. Educational Research, 43(2), 133-146.

Hymel, S., \& Swearer, S. M. (2015). Four decades of research on school bullying: An introduction. American Psychologist, 70(4), 293.

Keltner, D., Capps, L., Kring, A. M., Young, R. C., \& Heerey, E. A. (2001). Just teasing: a conceptual analysis and empirical review. Psychological bulletin, 127(2), 229.

Kennedy, T. D., Russom, A. G., \& Kevorkian, M. M. (2012). Teacher and administrator perceptions of bullying in schools. International journal of education policy and leadership, 7(5).

Land, D. (2003). Teasing apart secondary students' conceptualizations of peer teasing, bullying and sexual harassment. School Psychology International, 24(2), 147-165.

Losey, R. A. (2009). An Evaluation of the Olweus Bullying Prevention Program's Effectiveness in a High School Setting (Doctoral dissertation, University of Cincinnati).

Mann, M. J., Kristjansson, A. L., Sigfusdottir, I. D., \& Smith, M. L. (2015). The Role of Community, Family, Peer, and School Factors in Group Bullying: Implications for School-Based Intervention. Journal of school health, 85(7), 477-486.

Marshall, M. L., Varjas, K., Meyers, J., Graybill, E. C., \& Skoczylas, R. B. (2009). Teacher responses to bullying: Self-reports from the front line. Journal of school violence, 8(2), 136-158. 
Bullying at Aceh Modern Islamic Boarding Schools (Pesantrens)

Monks, C. P., \& Smith, P. K. (2006). Definitions of bullying: Age differences in understanding of the term, and the role of experience. British Journal of Developmental Psychology, 24(4), 801-821.

Nilan, P. (2009). The 'spirit of education'in Indonesian pesantren. British journal of sociology of education, 30(2), 219-232.

Oliver, C., \& Candappa, M. (2007). Bullying and the politics of 'telling'. Oxford Review of Education, 33(1), 71-86.

Padgett, S., \& Notar, C. E. (2013). Bystanders Are the Key to Stopping Bullying. Universal Journal of Educational Research, 1(2), 3341.

Parault, S. J., Davis, H. A., \& Pellegrini, A. D. (2007). The social contexts of bullying and victimization. The Journal of Early Adolescence, 27(2), 145-174.

Pfeiffer, J. P., \& Pinquart, M. (2014). Bullying in German boarding schools: A pilot study. School Psychology International, 35(6), 580-591.

Pohl, F. (2006). Islamic education and civil society: Reflections on the pesantren tradition in contemporary Indonesia. Comparative Education Review, 50(3), 389-409.

Rabah, J. Y., \& Vlaardingerbroek, B. (2005). Teachers' and administrators' perceptions of the bullying problem in Lebanon. Mediterranean Journal of Educational Studies, 10(2), 115-123.

Rahmawati, S. (2016). Hubungan Antara Kecemasan Perpisahan Dengan Orang Tua Terhadap Risiko Perilaku Bullying Santri di Pesantren Assanusi Cirebon.

Raihani, R. (2001). "Curriculum construction in the Indonesian pesantren: a comparative case study of curriculum development in two pesantrens in South Kalimantan."

Repo, L. (2015). "Bullying and its prevention in early childhood education."

Rigby, K. (2014). How teachers address cases of bullying in 
schools: a comparison of five reactive approaches. Educational Psychology in Practice, 30(4), 409-419.

Sekol, I. (2016, June). Bullying in adolescent residential care: the influence of the physical and social residential care environment. In Child \& Youth Care Forum (Vol. 45, No. 3, pp. 409-431). Springer US.

Vignato, S. (2012). Devices of oblivion: how Islamic schools rescue'orphaned'children from traumatic experiences in Aceh (Indonesia). South East Asia Research, 20(2), 239-261.

Williford, A., Boulton, A., Noland, B., Little, T. D., Kärnä, A., \& Salmivalli, C. (2012). Effects of the KiVa anti-bullying program on adolescents' depression, anxiety, and perception of peers. Journal of abnormal child psychology, 40(2), 289-300.

Yoon, J. S. (2004). Predicting teacher interventions in bullying situations. Education and Treatment of Children, 37-45. 